\title{
COLOR MATTERS
}

\section{Race, Ethnicity, Crime, and Justice in Uncertain Times}

\author{
Ruth D. Peterson
}

Department of Sociology, Ohio State University

\author{
Lauren J. Krivo \\ Department of Sociology and Program in Criminal Justice, Rutgers University- \\ New Brunswick
}

\section{Katheryn Russell-Brown}

Levin College of Law and the Center for the Study of Race and Race Relations, University of Florida

[C]rime is a difficult subject to study, more difficult to analyze into its sociological elements, and most difficult to cure or suppress. It is a phenomenon that stands not alone, but rather as a symptom of countless wrong social conditions.

-W. E. B. Du Bois, The Philadelphia Negro: A Social Study (1899 [1973], pp. 241-242)

Race and ethnicity are central defining characteristics of the social and structural conditions underlying crime and criminal justice processing in the United States and elsewhere. ${ }^{1}$ Yet, some are only now recognizing and giving credence to this reality. This recognition comes in the wake of publicity surrounding such recent events as: killings of persons of color by police or citizens claiming self defense, fear of harm, or other rationales that diminish culpability for lethal injuries; changing immigration policies affecting the deportation of otherwise law abiding immigrants, and related policies barring immigration from select (largely Muslim) countries; and publications highlighting the detrimental and inequitable consequences of mass incarceration (e.g., Alexander 2010; Travis et al., 2014). While media coverage of such events has raised awareness of the racial patterning of crime and justice, the connections between race, crime, and criminal justice are longstanding public concerns. Further, they have deep historical roots, whose character and manifestations reflect changing racial and ethnic dynamics in a diverse society that has by no means achieved post-racial status.

Scholarly efforts to understand and account for racial and ethnic disparities in crime and justice are also longstanding as suggested by the above epigraph from W. E. B. Du Bois' (1899 [1973]) nineteenth century book on The Philadelphia Negro. Du Bois' insight that the racial patterning of crime and justice does not stand alone but rather is

Du Bois Review, 15:1 (2018) 1-11.

(C) 2018 Hutchins Center for African and African American Research 1742-058X/18 \$15.00

doi:10.1017/S1742058X18000127 
embedded within the historical and structural positioning of racial and ethnic groups in society is as true today as when he wrote it over 100 years ago. ${ }^{2}$ Given this racial reality, a large body of work has examined inequalities in crime and criminal justice. Yet, many scholars and commentators are not convinced that we have achieved the type of deep understanding of how race, ethnicity, crime, and justice are interrelated that Du Bois' words require. For example, nearly a century after Du Bois' publication, Robert J. Sampson and William Julius Wilson note, “criminologists have reduced the race-crime debate to simplistic arguments about culture versus structure ... [and] with few exceptions [have] abdicated serious scholarly debate on race and crime" (1995 p. 38; see also, Russell 1992).

To push serious discussions of race, crime, and justice forward, the three of us have sought to improve the quality of research through critical scholarship, writings that set research agendas, and developing institutional resources that facilitate bringing into the mainstream of criminology the full array of perspectives and approaches offered by scholars of all colors. In this volume, we bring together research that builds on Du Bois and related traditions, including our own earlier work, in the interest of advancing critical thinking and analyses of the social, structural, cultural, and historical interconnections of race, crime, and criminal justice.

Working together, two of us have advocated for putting race and ethnicity at the center of crime and justice research (e.g., Krivo and Peterson, 1996, 2000; Krivo et al., 2009; Peterson 2012; Peterson and Krivo, 2010). We have also called upon scholars to embed research on this topic not simply within criminological theories, but also within a broader understanding of the racial organization of society. Taking this approach, our work illuminates how racial residential segregation sets the context for a host of racially inequitable macrostructural conditions that produce large differences in crime between White, Black, Latino, and other neighborhoods. By implication, creating a social order in which structural conditions (e.g., disadvantage, spatial location) are equal would largely equalize crime levels across racially distinct communities. Representative of our efforts, early on, the third member of our team called for development of a Black criminology as a corrective to the field's failure to produce a comprehensive account for why race and crime are closely connected (Russell 1992). This work additionally emphasized addressing the scarcity of scholars of color, whose experiences and interests, if applied to theory development, would advance understanding of the race-crime relationship. Also notable, The Color of Crime makes clear how media portrayals and powerful stereotypes of racial groups contribute to racial hoaxes, ${ }^{3}$ police harassment, and other macroaggressions (Russell 1998; Russell-Brown 2009). In the first edition, the term criminalblackman was coined to describe how, in the minds of U.S. residents, street crime is almost synonymous with young black males, though historical reality belies this stereotypic image (Russell 1998).

As 2016 President of the American Society of Criminology (ASC) and Co-Chairs of the 2016 annual meeting of the association, the three of us had the chance to work together closely. ${ }^{4}$ Not surprisingly, we chose "The Many Colors of Crime and Justice" as the theme for the meeting. Further, early on we discussed the possibility of creating a product that would serve as a lasting legacy acknowledging the election of the first African American President of the Society, and celebrating the opportunity to have a meeting that emphasizes race as a core component of the field of criminology. The result is this volume of articles, which highlights that, and how color matters in crime and justice. Here, we seek to bring this point to a broad audience of academics, policymakers, and others interested in the role of race and ethnicity in society, while simultaneously paying tribute to the legacy of scholars like Du Bois, who laid the groundwork for building a deeper understanding of the race and crime connection. 


\section{THE ARTICLES}

The articles and authors included in this volume grew from the 2016 ASC presidential plenary sessions and from other meeting presentations that complemented the content of the plenaries. The presidential sessions were designed to showcase the diversity of scholars and perspectives that contribute to our understanding of crime and justice around the world. They also focused on revealing important substantive findings and conclusions regarding race and ethnicity that flow from such diversity. ${ }^{5}$ The resulting articles fall into three categories: "Understanding Race, Crime, and Justice in the Twenty-First Century," which includes works addressing how race, crime, and justice are connected with "countless wrong social conditions" in the twenty-first century; "Policies, Politics, and the Plight of Racial and Ethnic Groups," which includes articles exploring how the character and implementation of justice policies themselves affect the fate of persons and groups of different colors; and "Critical Views on Race, Rights, and Criminal Justice" that provides critical perspectives on how to move forward to better understand the race-crime-justice relationship, while paving the way for lasting solutions to racialized justice processes and unduly high crime among groups of color. What follows are brief descriptions of each of the articles within its respective category.

\section{Understanding Race, Crime, and Justice in the Twenty-First Century}

In 1995, Sampson and Wilson published "Toward a Theory of Race, Crime, and Urban Inequality." In this article, they argued that "the discussion of race and crime is mired in an unproductive mix of controversy and silence" (1995, p. 37), and called upon researchers to rectify this situation by giving attention to the macrostructural underpinnings of the race-crime link. Echoing Du Bois, their call rested on the view that what appears to be racial variation in crime instead reflects "structural differences among communities, cities, and states in economic and family organization" (1995, p. 41). Sampson and Wilson's article was a watershed moment for the study of race, ethnicity, and crime. Scholars took on their agenda, producing a sizeable body of research that speaks to the merits of their macrostructural perspective, especially its fundamental claim now known as the racial invariance hypothesis. In the current volume, Sampson and Wilson, joined by Hanna Katz, reassess the perspective that they put forth in 1995 in light of the growing body of work on the structural sources of crime across race. In turn, they lay out an agenda for future research to advance the race-crime knowledge base, and point to potential policies that flow from existing findings. Three of their primary conclusions are that: 1) there has been considerable progress in research on race and crime since 1995; 2) overall, studies demonstrate that the core elements of the racial invariance perspective have broad empirical support; and 3) additional work is needed to carefully measure and test the mechanisms linking racial status with variation in levels of crime across a range of types of groups and areas.

As she did during the ASC plenary, María Vélez comments here on the Sampson, Wilson, and Katz article. In general, her remarks support their assessment regarding progress in knowledge on the structural sources of crime across units of different colors, and that these appear to be generally racially invariant. She also concurs with many of Sampson and colleagues' critiques of extant work and recommendations for future research. However, Vélez offers additional suggestions for advancing knowledge. For example, Sampson and colleagues conclude that there is overall support for their perspective because the directions of effects of key structural variables (e.g., disadvantage) are the same across groups or areas of different colors; they do not require that the 
magnitude of effects be similar. Vélez, on the other hand, sees value in assessing similarity in the magnitude of effects to gain insight into the ways political and social conditions of specific groups of different colors can diverge and either diminish or enhance structural influences on crime. Vélez also elaborates on aspects of culture not identified by Sampson and colleagues that need further conceptualization and measurement for improved understanding of racial differences in levels of crime.

The remaining two articles in this section exemplify types of progress made in recent studies of race and crime. Both assess change over time to explore whether and how shifts in economic conditions, political regimes, racial politics, and other aspects of social context affect the relationship between race, ethnicity, and crime. Of particular concern is the impact of the post-2000 downturn in the U.S. economy on criminal inequality. Lauren Krivo, María Vélez, Christopher Lyons, Jason Phillips, and Elizabeth Sabbath ask how the changing dynamics of the Great Recession and the American crime decline affected racial and ethnic disparities in neighborhood crime for eighteen U.S. cities between 1999 and 2013. They discover that violent and property crime declined in most neighborhoods consistent with the crime decline evident for the United States as a whole and for many cities during this period. However, not all neighborhoods experienced decreasing crime; homicide and burglary actually increased in some local areas. This countertrend is highly racially inequitable, largely being limited to Black neighborhoods. Further, disadvantage and housing instability were notably higher in neighborhoods that experienced increasing rather than declining or stable levels of crime. These results highlight the unequal consequences for crime of recent economic upheavals that have widened the racial divide in crime in the new century and decreased safety in some of the most marginalized communities in the United States.

Janet Lauritsen, Karen Heimer, and Joseph Lang bring closure to our discussion of racial and ethnic patterns of crime in the early twenty-first century. Relying on National Crime Victimization Survey data and theoretical ideas from William Julius Wilson's (1978) classic book on The Declining Significance of Race, they consider the factors that account for the relationship between serious male violent victimization and race and ethnicity. Specifically, Lauritsen and colleagues examine whether the influence of individual characteristics on victimization is the same across race and ethnic groups; and, whether the relationship between violent victimization and race diminished from 1973 through 2010, a period that includes the recession of the 2000s. They show that sociodemographic factors, particularly poverty, urban residence, employment, and age, account for most of the Black-White and Latino-White gaps in individuals' risks of victimization, consistent with racial invariance themes emphasizing racial structure. However, the links between race, ethnicity, and victimization persist at similar levels throughout the four decades even though the impact of poverty grew for Blacks and Whites consistent with Wilson's (1978) perspective on the increasing importance of economic position in determining one's life chances.

\section{Policies, Politics, and the Plight of Racial and Ethnic Groups}

The second set of articles offer analyses of the administration of justice. The authors ask how laws, criminal justice policies, or the politics of implementation affect the plight and life chances of racial and ethnic groups within and outside the justice system. Answering this question sheds light on the contributions of laws, criminal justice policies, and implementation practices to the quality of justice, legitimacy of the system, and promotion of inclusion or exclusion of groups in contemporary U.S. society. Each article speaks to how given policies affect redress for victimization, criminalization, 
or other justice and societal outcomes for a particular group(s): Native women; Latinos with and without legal status; Blacks in Chicago neighborhoods; or, prisoners of different colors serving time in California institutions.

Sarah Deer introduces readers to fundamental aspects of federal Indian law and examines how they affect (i.e., undermine) the criminal authority of tribal nations, and in turn, the disposition of cases involving violence against Native women. She first establishes the widespread nature of the problem of such violence, demonstrating that more than half of women living in Indian country experience some form of sexual assault in their lifetimes. Further, Native women are more likely to be victimized by non-Native perpetrators than by Indians. Yet, laws governing Indian authority insulate non-Indians from being held accountable for their crimes by tribal nations. At the same time, they give the federal government authority over serious crimes committed by people in Indian country although the U.S. government shows little interest in pursuing such cases. In combination, these provisions fail to redress criminal violence against women in Indian country. That is, they do not bring just desserts, deterrence, or incapacitation, and as such do not protect Native women from sexual assault and other forms of violence. Deer reveals other aspects of federal law that make it difficult to protect Native women from predatory crimes. These include prohibitions against stiff penalties for those who are prosecuted (e.g., a maximum of three years imprisonment in Indian country), and rules of criminal procedure that virtually price tribal courts out of the market for prosecuting cases.

Continuing with the role of federal policies in local contexts, Cecilia Menjívar, William Paul Simmons, Daniel Alvord, and Elizabeth Salerno Valdez bring attention to Latinos and their relations with local police in light of federal programs in which some police forces work in direct cooperation with U.S. Immigration and Customs Enforcement in implementing immigration laws. Studying Latinos in Chicago, Los Angeles, Houston, and Phoenix, the authors seek to determine: 1) whether those in Houston and Phoenix, where the police are more closely involved with federal enforcement efforts, are less likely to report crimes than Latinos in Chicago and Los Angeles, where local authorities participate less in federal immigration enforcement; and 2) if there are spillover effects from enforcement against undocumented immigrants to immigrants with papers or to native Latinos. They demonstrate that the willingness of Latinos to report crimes to the police is lowest in Phoenix, a city that is "... perhaps ... the most notorious anti-immigrant jurisdiction in the United States." However, an unwillingness to report crime spills over from undocumented immigrants to immigrants with documents, and almost to native born Latinos in all of the contexts except Chicago-a place that has been a sanctuary city since 1985 . Thus, a broad swath of presumably law abiding Latinos is negatively affected by immigration enforcement policies that make them fear deportation and criminalization. As such, the broader Latino community pays the price of authorities equating being Latino with illegality in ways that foster discrimination and exclusion.

The article by John Hagan, Bill McCarthy, and Daniel Herda highlights the role that politicians can play in developing, enacting, and implementing laws in racially patterned ways. They explore this broad issue for Chicago where the former mayor (1989-2011) Richard M. Daley (the son of earlier mayor Richard J. Daley) made "discretion an enacted part of the criminal law" along with "tightening the chains of command." Together these practices produced a rigidly organized criminal justice bureaucratic machine," with the explicit goal of increasing arrests and convictions, especially for drug crimes. The ultimate consequence was a punitive approach to drug law enforcement concentrated in African American neighborhoods and directed at 
young Black men. These punitive policies neither prevented crime in general nor protected Black or other communities from drug crimes in particular. Rather, Hagan and colleagues conclude that through its contributions to legal cynicism and resulting effects on crime (i.e., calls to police for assistance, official crime reports), Daley's approach laid a foundation for increasing and explosive demands for new mechanisms of police accountability. In this sense, the machine politics of Daley may have had intended negative and unintended positive race-based consequences.

In the final article in this section, Kitty Calavita and Valerie Jenness focus on a seldom examined phase of criminal justice: the implementation of prisoner grievance procedures, a consequential stage of justice because it is the route for prisoners to have their complaints about harmful living conditions and treatment heard in court. They note that, "[t]ens of thousands of prisoners in California file grievances with the California Department of Corrections (CDCR) every year, contesting such things as lack of medical care, unwarranted disciplinary actions, detestable physical conditions, and officer misconduct." Calavita and Jenness ask whether, in California, prisoners' views of the grievance process and outcomes are racialized similar to perceptions regarding other aspects of justice processing. They also examine whether prisoners are satisfied with the outcomes of their grievances if they view the grievance process as fair, a core claim of procedural justice theory and research. Interestingly, Calavita and Jenness find racial and ethnic similarity, rather than disparity, in California prisoners' views of the grievance process. Further, outcomes rather than process drive levels of satisfaction. Black, White, and Latino prisoners all view the grievance process as unsatisfactory unless cases are decided in their favor, which seldom occurs. Apparently, the extreme power of the carceral experience produces harms such that Whites' views begin to fall more in line with those of Blacks and people of other less valued colors.

\section{Critical Views on Race, Rights, and Criminal Justice}

To bring closure to this volume, we asked three scholars who have written on race, crime, and justice in scientific and policy contexts to comment on aspects of civil rights and criminal justice within their areas of expertise. The first critical essay, by Geoff Ward, discusses the history of racist violence and White supremacist policing, and its application to crime and justice in the twenty-first century. He explores the role of police in serving the interests of Whites at the expense of Black Americans' protection from criminal harms and exercise of their rights of citizenship. Relying on historical and contemporary case materials, Ward calls on scholars to use the historical record of racist violence in policing to bring the past to bear on present issues of racialized policing. Doing so enables us to see parallels with past practices and how policing functions today in explicit, implicit, and subtle ways to undermine the rights and wellbeing of Blacks and other groups and communities of color while facilitating the rights and wellbeing of Whites. Ward also warns policymakers and others interested in social change to not simply look to the future and dismiss the historical record as something that is dead and gone or irrelevant to current patterns if they are truly interested in transitioning to justice for all. Transformative justice can only come about when we face the history of White supremacist policing head on and in the fullest sense.

Ward acknowledges that police behaviors and motives can be affected by orientations that are explicit or stem from implicit bias. In her essay, Katheryn RussellBrown expresses considerable concern with the widespread credence being given to implicit bias in research and public discussions on race, crime, and criminal justice. 
Two fundamental issues are: how well the term implicit bias informs or obscures the reality of racial bias in criminal justice; and, whether research, as a foundation for policy, is served well by labeling racist behaviors on the part of criminal justice actors (and others) as reflecting implicit bias. Russell-Brown reminds us that as a label, implicit bias does not signal a racial bias; indeed, when it is associated with race, it is a colorblind reference. Neither does the term signal a harm or criminal wrong, culpability of the actor, or the need for an intervention. The appeal of implicit bias is also concerning because it can encourage people to take an overly simplistic approach that characterizes bias as either implicit or explicit, when in fact it may be both or neither. Even worse, scholars may lose sight of the fact that racial structure, historically and contemporarily, is at the base of both implicit and explicit racial bias. Also notable, Russell-Brown reminds us that being on the receiving end of unfair or unequal justice is equally devastating for the recipient whether the outcome stems from implicit bias, explicit bias, or bias of another form.

The final article in this volume is by Nancy Rodriguez, who recently completed a term as Director of the National Institute of Justice (NIJ; the research arm of the Department of Justice) during President Barack Obama's administration. Rodriguez makes the case that scientific advances can play a role in helping to provide "equal opportunity and justice for all youth." For example, she points to types of research that she feels lay the groundwork for policies that will be particularly useful in fostering children's rights and the wellbeing of youth, especially youth of color from disadvantaged backgrounds. This includes research on brain development in young people, the interplay between brain development and environment, children's risks of exposure to violence, and the role of legal counsel in court proceedings involving juveniles. In this sense, her discussion lays out a partial research agenda for scholars interested in youth of color and their positioning in the juvenile justice system. However, Rodriguez cautions that scholarship that is likely to be most helpful in advancing juvenile justice and civil rights generally has two common characteristics: it involves collaboration across disciplines, and therefore is grounded in multiple perspectives; and, it is informed by interactions between scholars, criminal justice professionals, and policymakers.

\section{CONCLUDING OBSERVATIONS}

We hope that you will read, learn from, and be stimulated by the articles in this special issue of the Du Bois Review. To further whet your appetite for doing so, we invite you to ponder our "top ten" take away points from the volume. These are based on the contents of individual or sets of articles (points 1-8) and extrapolations from the articles and comments made in the presidential plenaries at the 2016 ASC meeting (points 9 and 10).

1. There has been progress in understanding race, crime, and justice. Contemporary research on race, crime, and justice has made and continues to make progress in identifying and accounting for disparities in risks of crime and victimization and in levels of crime across colors of people and places.

2. Color still matters. Research indicates that color continues to impact crime in the twenty-first century, as it did in prior centuries. Moreover, color matters in a manner and for reasons noted in Du Bois' nineteenth-century arguments about the role of social conditions, and Sampson and Wilson's (1995) more recent call for a macrostructural approach in the study of race and crime. 
Specifically, observed racial disparities in crime are largely accounted for by social conditions, particularly aspects of disadvantage, which themselves reflect the positioning of individuals, groups, and locations in the racial structure of society.

3. Research on critical issues regarding race and crime is still needed. Recent progress notwithstanding, there is still a great deal to learn about additional mechanisms connecting race and ethnicity to crime, trends in this relationship (Krivo et al.; Lauritsen et al.), and policies that might address racial and ethnic disparities in crime across contexts and over time. Thus, while we applaud contemporary advances in knowledge, we urge scholars to press on to provide a broader and deeper understanding of these critical problems that have been with us for far too long.

4. Laws and justice policies contribute to racialized justice. Researchers are also contributing important knowledge on how laws, criminal justice policies, and practices implemented by justice officials cause color to still matter in criminal justice processes and outcomes. As documented in this volume, governments' own actions can be sources of underprotection, overcriminalization, or exclusion from society for broad swaths of the population, including Native women, Latinos(as), African Americans, and other segments of the population relative to Whites, belying the explicit goals of the State to provide constitutional guarantees of equal protection and justice for all.

5. Additional research is needed on the scope and variability of laws' and justice policies' contributions to racialized justice. Despite progress, additional case studies are needed to further identify which laws and policies affect particular groups in disproportionate and unfair ways and to expose how this works. As well, we need more comparative studies similar to those conducted by Menjívar and colleagues, to explore more thoroughly the scope of and variability in the consequences of laws, policies, and their implementation within and across settings and groups of different race and ethnic backgrounds.

6. Scholars (and policymakers) should be mindful of historical patterns in trying to understand crime and justice in the twenty-first century. As we continue to sort out how color matters for crime and criminal justice, we should be mindful to draw on historical evidence of the patterning and behavior of system actors and processes, not solely to set twenty-first-century patterns in historical context, but also for understanding and interpreting how contemporary patterns are imbued with history in the manner of Deer's and Ward's analyses.

7. Do not put all your conceptual eggs in the implicit bias basket. Implicit bias is proving to be a helpful construct for understanding some of the connections between race, ethnicity, crime, and justice in the United States. However, scholars should be careful not to rely exclusively on this construct, reflecting a cognitive process, as the answer to all questions regarding racial bias. This is critical because: 1) like bias of other forms (e.g., explicit, subtle, etc.), implicit bias is also rooted in the structural and racial organization of society; and 2) its consequences are no less harmful in thwarting equal justice than explicit bias.

8. Do not ignore the children. Most of the studies herein address general issues of crime or criminal justice for groups as a whole. However, Rodriguez's essay reminds us that race and ethnic disparities in victimization, criminalization, and justice system contact and embeddedness are evident at very early stages in the life course, complete with all the vagaries that flow from such experiences. Steps should be taken to address critical issues such as those noted by Rodriguez in the interest of building the knowledge base needed to reduce victimization and crime 
among juveniles, and foster equitable and quality justice for youth caught up in the juvenile and/or criminal justice systems. There may also be other distinct populations of color that should receive research attention (e.g., girls, immigrant groups, etc.).

9. Continue to bring the data. Efforts by scholars to better understand the race, ethnicity, crime, and justice relationship are essential, especially in times of uncertainty and racial tension. This is true for providing basic foundational knowledge that can have short-term or unforeseen long-term payoffs or consequences, and for providing evidence for those in the trenches today seeking to apply justice equally or reform the justice system to be more equitable. As we listened during the 2016 ASC plenaries to local justice officials, justice reform activists, and civil rights attorneys, one after the other pleaded with us to continue to "bring the data" and to "provide the findings" that allow them to tell the stories and make the case for substantive change. We implore our authors and other colleagues to continue to respond to this call.

10. Do not allow post-truth to win in the fight for justice. Our final takeaway is a reminder that the term post-truth, ${ }^{6}$ which describes a situation where objective facts are less influential than emotional appeals in public opinion and debates about public issues, has become a popular part of the atmosphere in the early 2000s. This is, in part, a result of the rhetoric that surrounded the 2016 U.S. presidential campaign and the political environment since then. For a subject as serious as race, crime, and justice, it is urgent that scientific communities, such as criminologists and sociologists, persist in producing quality research and sharing their findings broadly to ensure that there is a counter to post-truth for informing discussions about race and criminal justice and to serve as a basis for sound criminal justice decision making. The articles in this volume are exemplary in challenging post-truth while pushing for greater justice in the early twenty-first century.

Corresponding author: Ruth D. Peterson, Department of Sociology, Ohio State University, 238 Townshend Hall, 1885 Neil Ave., Columbus, OH 43210. E-mail: peterson.5@osu.edu

\section{ACKNOWLEDGMENT}

We are grateful to Lawrence Bobo who, as Editor, accepted our proposal and gave us the opportunity to develop this special issue of the Du Bois Review. We hope that the volume provides much food for thought for him and readers of the $D B R$ in general. We also thank Sara Bruya and Nicole Terez Dutton for their patience, hard work, and meticulous attention to our work in helping us bring the volume to fruition. Ramiro Martínez paved the way for our request to Professor Bobo, and we are grateful to him for doing so and for his own contributions to research on race, ethnicity, and crime. We also thank several anonymous reviewers for their critical assessments of early versions of some of the articles. Finally, no words can adequately communicate our appreciation to the authors of the articles in this volume. All of them agreed to contribute an article on our first ask, and they delivered these very fine papers while conforming to our timetable (always short) at every stage of the process, and our space demands (too limited) without complaint. It is a privilege to have such wonderful colleagues.

\section{NOTES}

1. Although we often refer to both race and ethnicity, throughout this introduction we use the term race (without ethnicity) as a general term incorporating both race and ethnicity. We also use the terms people and persons of color in an inclusive sense to mean a host of 
Black, Brown, Red, and other non-White people who, as a category, hold subordinate status in the United States. This includes, for instance, African Americans, Latino groups, and Native Americans.

2. In Chapter 14 of The Philadelphia Negro, Du Bois characterizes crime and justice participation, and changes in participation, of Blacks, then referred to as Negroes, in the local area. Throughout, the statistics presented are comparative (Whites versus Blacks, or Blacks as a proportion of the total [with primarily Whites presumably contributing the remaining portion]). In Chapter 15, he summarizes his views on the causes of poverty and crime among Blacks. His primary answer focuses on the environment, including: badly situated and managed homes, and economic exclusion.

3. Racial hoaxes are defined as acts such as the fabrication of a crime and blaming it on a person because of his or her race, or falsely blaming someone for an actual crime because of his or her race. Russell-Brown catalogs ninety-two such hoaxes in the second edition of her book, including those of Susan Smith, Jesse Anderson, Charles Stuart, and Jennifer Wilbanks.

4. Ruth (Peterson) was elected and proudly served as President of the American Society of Criminology (ASC) for 2016. One of the functions of the ASC President is hosting the Annual Meeting of the Society during her presidential year. Ruth asked the other two of us, Lauren (Krivo) and Katheryn (Russell-Brown), to serve as Co-Chairs of the 2016 ASC Program Committee. Enjoying the fellowship, the three of us collaborated in planning the program and editing this volume of the $D u$ Bois Review.

5. Our original plan was to include articles by scholars and members of the policy community (e.g., leaders of national civil rights organizations, community organizers, etc.), who participated in our plenary sessions, in dialogue with one another. However, in the wake of the election and inauguration of Donald J. Trump as the U.S. President, and his pronouncements of how he intended to handle issues such as immigration and crime, one by one, participants from the policy community withdrew from developing papers for this volume in favor of working to address issues in the new political environment. We regret that they did not have the opportunity to present their viewpoints here, but appreciate their work and respect the choice each made.

6. In 2016, the Oxford Dictionaries selected the term post-truth as its international word of the year after its usage rose by 2,000 percent over 2015. Oxford Dictionaries' word of the year "captures the mood of a particular year" and has "lasting potential as a word of cultural significance" (Wang 2016).

\section{REFERENCES}

Alexander, Michelle (2010). The New fim Crow: Mass Incarceration in the Age of Colorblindness. New York: The New Press.

Du Bois, W. E. B. (1899[1973]). The Philadelphia Negro: A Social Study. Philadelphia, PA: University of Pennsylvania Press.

Krivo, Lauren J., and Ruth D. Peterson (1996). Extremely Disadvantaged Neighborhoods and Urban Crime. Social Forces, 75(2): 619-648.

Krivo, Lauren J., and Ruth D. Peterson (2000). The Structural Context of Homicide: Accounting for Racial Differences in Process. American Sociological Review, 65(4): 547-559

Krivo, Lauren J., Ruth D. Peterson, and Danielle P. Kuhl (2009). Segregation, Racial Structure, and Neighborhood Violent Crime. American fournal of Sociology, 114(6): 1765-1802.

Peterson, Ruth D. (2012). The Central Place of Race in Crime and Justice-The American Society of Criminology's Sutherland Address. Criminology, 50(2): 303-328.

Peterson, Ruth D., and Lauren J. Krivo (2010). Divergent Social Worlds: Neigbborhood Crime and the Racial-Spatial Divide. New York: Russell Sage Foundation.

Russell, Katheryn K. (1992). Development of a Black Criminology and the Role of the Black Criminologist. Fustice Quarterly, 9(4): 667-683.

Russell, Katheryn K. (1998). The Color of Crime: Racial Hoaxes, White Fear, Black Protectionism, Police Harassment, and Other Macroaggressions. New York: New York University Press.

Russell-Brown, Katheryn (2009). The Color of Crime (2 ${ }^{\text {nd }}$ Ed.). New York: New York University Press. 
Sampson, Robert J., and William Julius Wilson (1995). Toward a Theory of Race, Crime, and Urban Inequality. In John Hagan and Ruth D. Peterson (Eds.), Crime and Inequality, pp. 37-54. Stanford, CA: Stanford University Press.

Travis, Jeremy, Bruce Western, and Stephens Redburn (Eds.) (2014). The Growth in Incarceration Rates in the United States: Exploring Causes and Consequences (Committee on Law and Justice, Division of Behavioral and Social Sciences and Education). Washington, DC: The National Academies Press.

Wang, Amy B. (2016). "Post-Truth" Named 2016 Word of the Year by Oxford Dictionaries. The Washington Post, November 16. <https://www.washingtonpost.com/news/the-fix/wp/2016/11/16/ post-truth-named-2016-word-of-the-year-by-oxford-dictionaries/?utm_term=.229d6bfb2188> (accessed April 15, 2018).

Wilson, William Julius (1978). The Declining Significance of Race: Blacks and Changing American Institutions. Chicago, IL: University of Chicago Press. 